\title{
Dijital Platform Kullanıcılarının İzleme Alışkanlıklarına Yönelik Bir Araştırma: Netflix Örneği ${ }^{1}$
}

\author{
Ümit SARI ${ }^{2}$ - Halil TÜRKER ${ }^{3}$
}

Başvuru Tarihi: 16.12.2019～Kabul Tarihi: 08.03.2021

Makale Türü: Araştırma Makalesi

\section{Öz}

Dijital platformların günlük izleme pratiklerinde oynadiğ 1 rol giderek artmaktadır. Yayıncılık ve bilişim teknolojilerinin kesiştiği noktada doğan dijital platformların kullanıcılarına sunduğu özelleştirilmiş hizmetler bireylerin izleme alışkanlıklarını etkilemekte ve şekillendirmektedir. Geleneksel televizyon yayıncılığında uzun yllar yalnızca ekrana getirileni izleyen ve edilgen bir konumda olan izleyici, günümüzde özellikle dijital platformlar yoluyla kişisel zevklerine hitap eden içerikleri izleme, geri bildirimde bulunma gibi seçeneklere sahip olarak aktif bir konuma yükselmiştir. Çalışmada dijital platform kullanıcılarının izleme alışkanlıklarının Netflix örneği üzerinden araştırılması amaçlanmıştır. Amaca göre örnekleme tekniği kullanılarak gerçekleştirilen araştırmada veri toplama tekniklerinden Bilgisayar Destekli İnternet Anketi (CAWI) tercih edilmiş ve veriler tam yapılandırılmış soru formu kullanılarak elde edilmiştir. Katılımcılara Netflix dijital platformu içeriklerini izleme alışkanlıkların ve tercih nedenlerini irdeleyici sorular yöneltilmiştir. Netflix'in yaygın uluslararası dijital platformlar arasında Türkiye'de faaliyet gösteren ilk platform olması çalışmaya konu olmasının başlıca sebebini oluşturmaktadır. Çalışmanın sonucunda dijital platform kullanıcılarının izleme alıskanlıklarına yönelik tespitlere ve tercih sebeplerine ulaşılmıştır. İçerik çeşitliliği, seçme özgürlü̆̈̈̈ ve yapımların kalite düzeyinin kullanıcıların dijital platformlardaki izleme alışkanlıklarını doğrudan etkilediği tespit edilmiştir. Ayrıca dijital platformlara yönelimin yakın gelecekte artarak devam edeceği çalışmanın sonuçları arasında yer almaktadır.

Anahtar Kelimeler: İzleyici, Dijitalleşme, Televizyon, Dijital Platformlar, Netflix

Atıf: Sarı, Ü. ve Türker, H. (2021). Dijital platform kullanıcılarının izleme alışkanlıklarına yönelik bir araştırma: Netflix örneği. Anadolu Üniversitesi Sosyal Bilimler Dergisi, 21(1), 59-80.

\footnotetext{
${ }^{1}$ Bu çalışma 2019 yılı içerisinde dergiye yayın başvurusunda bulunulmuş makale olduğundan geriye dönük etik kurul izni gerekmemektedir

${ }^{2}$ İstanbul Üniversitesi İletişim Fakültesi Radyo, Televizyon ve Sinema, sariumitt@gmail.com, ORCID: 0000-0003-1761-304

${ }^{3}$ İstanbul Üniversitesi İletişim Fakültesi Radyo, Televizyon ve Sinema, halilturker@istanbul.edu.tr, ORCID: 0000-0001-5776-3250
} 


\section{Giriş}

Görüntünün kalıcı hale getirilmesi ve bir noktadan diğerine aktarılmasına dair uzun yıllar farklı bilim insanları ve mucitler tarafından yürütülen çalışmalar sonucu ortaya çıkan televizyon, günümüzde geldiği noktada elektronik bir cihazın yanı sıra sosyolojik, kültürel ve hatta psikolojik anlamlar içermektedir. Toplumun 'televizyon dünyası' gibi bir kalıp kullanması, yabancı dizilerin yayınlandığı ülkelerdeki giyim tarzını etkilemesi ve aynı anda bir diziyi veya programı izleyen birden çok kişinin söz konusu yayındaki gelişmelere kızarak, üzülerek veya sevinerek tepki verip bu bağlamda kendi aralarında diyaloğa girmesi televizyonun bir cihaz olmaktan öteye geçtiğini kanıtlar niteliktedir.

Televizyon ve izleyici arasındaki ilişki uzun yıllar boyunca tek taraflı bir şekilde gerçekleşmiştir. Görüş belirtemeyen, katılım gösteremeyen ve yalnızca "izlemek" eylemini icra etmek ile yükümlü olan izleyici söz konusu ilişskide pasif taraf olmuştur. Bilişim ve iletişim teknolojilerindeki gelişmeler elbette televizyon yayıncılı̆̆1 üzerinde de etkiler göstererek günümüze uzanan köklü değişikliklerin başlangıç noktasını oluşturmuştur. 1990'lı yıllardan itibaren televizyon yayınlarına faks çekerek veya telefon yoluyla bağlanarak görüş bildirmek ve istekte bulunmak gibi eylemler yıllarca pasif durumda olan izleyicinin nispeten daha aktif bir konuma yükselmesinde atılan önemli adımlar olmuştur. Takip eden süreçte izleyici medya metinlerini yeniden oluşturan, yorumlayan ve anlamlandıran hale gelmiştir (Uluç, 2008, s. 116).

Televizyon-izleyici ilişkisinde en önemli kırılma noktasını günümüzde yeni medya başlığı altında kavramsallaştırılan sosyal ağların kullanımının yaygınlaşması oluşturmuştur. Facebook, Twitter, Youtube gibi sosyal ağların yaygınlaşması ve yayıncılık teknolojileriyle entegre hale gelmesi izleyiciyi yeni bir boyuta taşımıştır. İzlediği içeriğe sosyal ağlarda anında yorum yapabilen, topluluklar oluşturup senaryo yazarlarını etkileyerek dizilere yön verebilen, ana haber bültenlerindeki haberleri eleştirerek spikerleri açıklama yapmak ve zaman zaman özür dilemek zorunda bırakan aktif ve belirleyici rolde olan bir izleyici varlığından söz edilir noktaya gelinmiştir.

Bilişim ve iletişim teknolojilerindeki gelişmeler televizyon yayıncılığını elbette yalnızca izleyici özelinde etkilemekle kalmayıp icra edilme şeklini de köklü düzeyde etkilemiştir.

2010’lu yılların başlarından itibaren Youtube gibi video paylaşım siteleri bireysel üyelerin yanı sıra medya şirketleri gibi kurumsal üyeler tarafından kullanılmaya başlanmış ve televizyon kanallarındaki ulusaluluslararası yayınların tekrarları internet ortamında izlenilir hale gelmiştir. Televizyonlar daha sonra canlı yayınlarını eş zamanlı olarak internet ortamına taşımış ve izleyiciler söz konusu kanalların özellikle kurumsal web sayfaları ve Youtube hesaplarından bu yayınları izleme olanağına erişmişlerdir. Görüntü teknolojilerinin tablet ve akıllı telefon gibi mobil cihazlarla entegre olmasıla birlikte internet ortamındaki yayınların masa başı bilgisayarlara bağlı kalınmadan hareket halindeyken dahi izlenilebilir hale gelmesi izleme deneyimini değiştirirken yayıncıları da bu yeni izleyici modelini etkilemek ve yakalamak için alternatif yollar aramaya yöneltmiştir.

İnternetin bireye kazandırdığı içerik seçme özgürlüğü günümüzde izleme davranışı üzerinde de etkisini göstermektedir. Bireyler izlemek istedikleri içeriğe yer ve zaman fark etmeksizin ulaşabilmektedirler. Arzu edilen içeriğe ulaşma ve izleme davranışı medya yöneticilerinin bu arzuya çeşitli işlevler yoluyla hizmet eden yeni bir ortam geliştirmelerini sağladı: Dijital platformlar.

İçeriklerin kategorize edilmesi, kişinin izlediği içeriklerden yola çıkıp benzer içerik önerilerinde bulunması, çoklu dil-altyazı seçeneğinin yanı sıra reklamsız izleme deneyimi sunması gibi özellikleri nedeniyle son yıllarda dünya çapında yükselişe geçen dijital platformlar yayıncılıkta adeta yeni bir dönemi başlatmış ve beraberinde izleme alışkanlıklarında da önemli değişiklikleri getirmiştir 
Dijital platform kullanıcılarının izleme alışkanlıklarının onların aktif izleyici olma konumuna etki edip etmediğini saptamak bu çalışmanın sorunsalını oluşturmaktadır.

Bu çalışmada dijital platform kullanıcılarının izleme alışkanlıkları dünyanın en yaygın dijital platformlarından biri olan Netflix’in kullanıcıları baz alınarak incelenmiştir. Çalışmanın oluşturulmasında 1950'li yıllarda Elihu Katz tarafından temeli atılan (Erdoğan ve Alemdar, 1990) ve tarihsel süreç içerisinde akademisyenlerin ve alan üzerine çalışan uzmanların katkılarıyla geliştirilerek günümüzde geçerliliğini korumakta olan kullanımlar ve doyumlar yaklaşımından faydalanılmıştır. Bireylerin medya araçlarını nasıl kullandığı ve onlarla ne yaptığıyla ilgilenmesi (Özçetin, 2018, s. 113), izleyicilerin medya içeriklerini kullanma kapasiteleri üzerine yoğunlaşması (Yaylagül, 2006, s. 71) ve bu çerçevede izleme alışkanlıklarının oluşmasındaki etkenlerin saptanmasındaki rolü kullanımlar ve doyumlar yaklaşımının bu çalışmanın kuramsal tabanını oluşturmasındaki en önemli sebeplerin başında gelmektedir.

Amaca Göre Örnekleme (Purposive Sampling) tekniği kullanılarak gerçekleştirilen nicel araştırmada (Thompson,1997) veri toplama tekniklerinden Bilgisayar Destekli İnternet Anketi (CAWI) tercih edilmiş ve veriler tam yapılandırılmış soru formu kullanılarak elde edilmiştir. Araştırma örneklemine dahil olan Netflix kullanıcısı kitleye izleme alışkanlıkları, tercih sebepleri ve dijital platformlara olan yaklaşımlarına dair sorular yöneltilmiştir.

$\mathrm{Bu}$ çalışma dijital bir platformun kullanıcılarının (Netflix) izleme alışkanlıklarına ait detaylı bilgileri elde etmek üzere yapılmıştır. Söz konusu kitleye erişim olasılık hesaplarına bağlı olarak gerçekleşememektedir. Bunun sebebi Netflix şirketinin kurumsal bir politika olarak kullanıcı verilerini kamuoyu ve araştırmacılar ile paylaşmamasıdır. Amaca Göre Örnekleme tekniği özel bir amaç çerçevesinde yapılan araştırmalarda en güvenilir sonuca götürecek örneklem kitlesine ulaşmada kullanılan önemli bir teknik olarak öne çıkmaktadır. Söz konusu durum Amaca Göre Örnekleme tekniğinin bu çalışmada kullanılmasının başlıca sebebini oluşturmaktadır.

Veriler çeşitli detaylarıyla bulgular bölümünde açıklanmıştır. Sonuç ve tartışma bölümünde ise araştırmanın bulgularından yola çıkılarak aktif izleyicinin rolü Henry Jenkins’in katılımcı kültür ve kolektif zekâ kavramları üzerinden tartışılmıştır.

Bireyler ve medya arasındaki ilişki geride bırakılan yarım asır boyunca başta iletişimciler ve sosyologlar olmak üzere sosyal bilimcilerin en önemli çalışma alanlarından biri olmuştur. Küreselleşmenin ve dijitalleşmenin etkisiyle medya bireylerin yaşamının adeta her alanına nüfuz eder hale gelmiştir ve izleyici araştırmaları önemini korumayı sürdürmüştür. Dijitalleşmenin enformasyon ve iletişim sinyallerinin üretimini, yayılmasını ve tüketimini büyük ölçüde artırması bu durumun başlıca nedenini oluşturmaktadır (Dijk, 2018, s. 297).

Günümüzde birey-medya arasındaki ilişki iletişim, sosyoloji, psikoloji, ekonomi ve siyaset bilimciler tarafından incelenecek düzeyde geniş ve çok disiplinli bir alan üzerinde şekillenmektedir. Geçmişte ve günümüzde yapılan çalışmaların kesiştiği en önemli nokta ise bireylerin medya ürünlerine ulaşmalarında ve tüketmelerindeki en önemli faktörlerin başında sosyal ve psikolojik ihtiyaçlarının gelmekte olduğudur. Bu noktada geçmişten günümüze çeşitli katkılarla geliştirilen ve geçerliliğini korumayı sürdüren kullanımlar ve doyumlar yaklaşımı ön plana çıkmaktadır.

İzleyici araştırmalarına yönelik çalışmalarda en önemli referans noktalarının başında gelen kullanımlar ve doyumlar yaklaşımı kendisinden önce yapılan etki araştırmalarının aksine medyanın insanlara ne yaptığı yerine insanların medya ile ne yaptı̆̆ına odaklanmaktadır. Psikolog Elihu Katz’ın çalışmalarıyla temeli atılan ve izleyicilerin medyaya yalnızca maruz kalan değil aynı zamanda etki eden bir unsur olduğunun savunulduğu yaklaşım aktif izleyici çalışmalarının da temelini oluşturmuştur. Kişilerin medyayı nasıl kullandığını anlamaya çalışan psikolojik bir iletişim yaklaşımı olan (Özçetin, 2018, s. 113) kullanımlar ve doyumlar yaklaşımında dünya ile girdiğimiz ilişki "gereksinimlerimiz" aracılı̆̆ıyladır ve yaşamda yolumuzu aydınlatan bizim bu 
gereksinimlerimizi tatmin etme arzumuzdur (Mutlu, 2005, s. 352). Çalışmaya konu olan dijital platformlar bu noktada önem kazanmaktadır. Bireysellik ve konfor anlayışına atfedilen önemin her geçen gün arttı̆̆ 1 günümüz dünyasında dijital platformlar izleyicilerine/kullanıcılarına sunduğu çeşitli seçenekler ve içeriklerle onların tatmin olma arzusuna hizmet etmektedir. Burada söz edilen "tatmin olma" durumu bireylerin diledikleri medya içeriğine erişerek doyuma ulaşmalarıdır. Greenberg'e göre kişiler iletişim araçlarında dinlenme, yalnızlığı giderme, eğlence, heyecan ve sorunları unutma gibi doyumlar aramakta ve elde etmektedirler (Erdoğan ve Alemdar, 1990, s. 110).

Medya içeriği ile izleyici arasında işlevsel bir ilişki olduğu kabul edilen kullanımlar ve doyumlar yaklaşımından yararlanan araştırmalar izleyicilerin kendi ihtiyaçlarına ve isteklerine uygun medya içeriklerini aramaları, bulmaları ve kullanma kapasiteleri üzerine yoğunlaşmaktadır (Yaylagül, 2006, s. 71). Söz konusu işlevsel ilişki kullanımlar ve doyumlar yaklaşımına bu çalışmada değinilmesinin en önemli nedenlerinden birini oluşturmaktadır. İzleyicinin pasiflikten sıyrılarak aktif bir şekilde konumlandırıldığı dijital platformlar bu işlevsel ilişkinin başlıca örneklerinden olma özelliği taşımaktadır. Ayrıca yaklaşım izleyicileri aktif, akılcı, etkiye karşı direnen ve isteklerine göre seçim yapan bireyler olarak kabul etmektedir (Erdoğan ve Alemdar, 1990, s. 109).

Dijital platformlar ve izleyici alışkanlıkları ilişkisi üzerine son dönemde yapılan bazı çalışmalarda ulaşılan sonuçları belirtmek faydalı olacaktır. Başer ve Akıncı kullanıcı deneyimi ve kişiselleştirme bağlamında Netflix’i incelediği çalışmasında amaçlı örneklem kapsamında belirlediği 17 Netflix abonesi ile derinlemesine görüşme yapmıştır. Çalışmada kullanıcıların abonelik kararlarında kişiselleştirmeye ve kullanıcı deneyimine önem verdikleri sonuç olarak öne çıkmıştır (Başer ve Akıncı, 2020, s. 866). Katmer ve Sevindi ise Netflix’in izleme pratiklerinde yaptığı değişiklikleri konu edindiği çalışmasında gençlerin geleneksel televizyondan uzaklaşmasına neden olan faktörleri irdeleyerek Netflix'in hangi noktalarda farklılaştığına yönelik tespitler yapmıştır (Katmer ve Sevindi, 2020, s. 57). Ateşalp ve Başlar'ın aşırı izleme (binge-watching) ile ilgili odak grup görüşmesine dayalı çalışmasında Katılımcıların neden ve nasıl aşırı izleme yaptıkları ve aşırı izlemeye dair görüşleri anlaşılmaya çalışılmıştır. Katılımcılar görüşmelerde aşırı izleme deneyimine dair görüşlerini aktarırken, aşırı izlemenin vakit kaybına, yorulmaya, sersemliğe neden olduğunu, bağımlılık yarattığını ifade etmişlerdir. Fakat bu izleme deneyimine dair olumsuz görüşlerine rağmen katılımcıların odaklanarak izlemek, spoiler almamak, diziler hakkındaki konuşmalara katılarak sosyalleşebilmek, boş vakitlerini değerlendirmek, gündemden kaçmak gibi nedenlerle aşırı izleme yapmayı tercih ettikleri görülmüştür (Ateşalp ve Başlar, 2020, s. 110).

\section{Aktif İzleyici, Yeni Medya ve Dijitalleşme}

İlk televizyon yayınının (1936) gerçekleştiği günden itibaren televizyondan ayrı düşünülemeyen izleyici kavramı tarihsel süreç içerisinde çeşitli aşamalardan geçerek anlam ve bağlam değişikliğine uğramıştır. 1960'lara kadar yalnızca ekranın kendisine verdiğine maruz kalan, içeriğin belirlenmesinde herhangi bir etkisi bulunmayan ve yalnızca 'etkilenen-pasif konumda olduğu savunulan izleyiciye yönelik bakış açısı bu tarihlerden itibaren değişmeye başlamıştır. Elihu Katz’’n öncülük ettiği bilim insanları, uzmanlar ve araştırmacılar izleyicilerin medya üzerindeki etkisine yoğunlaşmışlardır (Erdoğan ve Alemdar, 1990). Yapılan çalışmalarda izleyicinin savunulanın aksine "etkileyen-aktif” bir konumda olduğu görüşüyle hareket edilmiştir.

İletişim ve internet teknolojilerindeki gelişmeler izleyicinin tarihsel süreç içerisindeki kimliğinin şekillenmesinde etkili rol oynamıştır. 1980'lerde küreselleşme hareketlerinin hızlanması ve 1990'ların başında internetin halkın kullanımına açılarak hızla yaygınlaşması kitle iletişiminde önemli değişiklikleri beraberinde getirmiştir. İnternet ve uydu teknolojilerindeki gelişim yayıncılık şeklini değiştirmeye başlamış ve uluslararası haber/yayın akışı hızlanmıştır. Medyanın küreselleşmesinin getirilerinden biri olarak medya ürünlerinin daha geniş sınırlar içinde dolaşımı başlamıştır (Uluç, 2008, s. 211). Diziler dâhil olmak üzere televizyon içeriklerinin 
uluslararası dolaşıma girmesi izleyiciyi içerik seçimi açısından daha bilinçli hale getirmeye başlamıştır. Ancak bilinçlenen izleyicinin dilediği içeriğe dilediği zaman ulaşabilme seçeneğine sahip olması için web teknolojisinin gelişmesi, etkileşim ve yöndeşmenin artması, televizyon yayıncılığının platformlara taşınarak kişiye/kişilere özel hizmet verir hale gelmesi gerekmekteydi. Günümüz dünyasındaki iletişim/yayıncılık sistemleri bu dinamikler üzerinde şekillenirken 1990'lı yılların perspektifinden bakıldığında dönemin koşullarının izleyiciyi bir süre daha pasif konumda bıraktığı görülmektedir.

Birden fazla haberleşme ağının (network), birlikte meydana getirdikleri bir iletişim ortamı (platform) olarak tanımlanabilen internet (Uluç, 2008, s. 20), izleyicinin günümüz anlamında aktif konuma yükselmesi sürecinde önemli bir yer tutmaktadır. Halkın kullanımına Web 1.0 ile açılan internet tek taraflı bir deneyimi temsil etmekten öteye geçememiştir. İçeriği almakla yetinmek zorunda kalan ve bundan dolayı pasif durumda olan birey Web 2.0 ile içeriğe katkı sunabilir hale gelerek aktif (katılımcı) bir konuma yükselmiştir. Etkileşim kavramının doğurduğu süreç zaman içinde yöndeşmenin de gelişmesiyle benzer durumun izleyiciler nezdinde yaşanması sonucunu beraberinde getirmiştir. İnternet, insanların iletişimde bulunabilme mekânlarına bir yenisini eklemiştir (Timisi, 2003, s. 147).

Telekomünikasyon, veri iletişimi ve kitle iletişiminin tek bir ortamda birleşmesi yöndeşme süreci olarak adlandırılabilmektedir (Dijk, 2018, s. 20). Akıllı telefonlar yöndeşmeye gösterilebilecek en önemli örneklerin başında gelmektedir. Telefon ana işlevi olan arama eylemini yerine getirmesinin yanı sıra bilgisayar gibi eposta göndermekte, müzik çalar ve televizyon ekranı işlevi görmektedir. Dijk, etkileşim kavramını ise birbiri ardına gelen etkiler ve tepkiler olarak tanımlamaktadır (2018, s. 21). Geleneksel ve yeni medya arasındaki en önemli ayrım etkileşimdir. Tek taraflı bir iletişimin söz konusu olduğu geleneksel medya izleyicileri/okurları etkileşim kavramı ile birlikte artık birer kullanıcı/üretici konumuna gelmişlerdir.

Yeni medya kavramı kitle iletişimini derinden etkileyerek beraberinde köklü değişiklikler getirmiştir. Söz konusu değiş̧iklikleri tarihsel perspektifte küreselleşme süreci bağlamında okumak gelinen noktayı çeşitli yönleriyle kavrama açısından faydalı olacaktır. Yeni medyanın bir metin olarak ele alındığı ve izleyicilerin de bu yeni metinlerle girdiği ilişki bağlamında sorgulandığı bu süreçte izleyicinin tanımı ve içeriği de değişmiştir. Üretim -tüketim ve yeniden üretim süreçleri boyunca, izleyiciden kullanıcıya, içerik tüketicisine, üreten tüketicilere doğru önemli bir dönüşüm gerçekleşmiştir (Özsoy, 2011, s. 113-114).

Dijitalleşme kavramı yayıncılık biçiminde köklü değişiklikleri beraberinde getirmiştir. Dijitalleşme her şeyin 1'ler ve 0'lardan oluşan dizilerin oluşturduğu ayrı ayrı bitlere dönüştürülebilmesi anlamına gelmektedir (Dijk, 2018, s. 293). Televizyon yayıncılığının dijitalleşmesi çalışmanın “Dijital Platformlar” başlığında ele alınmıştır. Dijitalleşmenin yayıncılığın icra biçimini etkilemesi zamanla içerik yapısına da yansımıştır. Yayınların platformlar aracılığıyla internet üzerinden abonelere ulaştırılması ve izleyicide bir süre sonra içeriğin çeşitlenmesi talebini oluşturmuştur. Günümüzde hizmet veren dijital platformlar hizmetlerini abone/kullanıc1/izleyicilerden gelen öneriler doğrultusunda geliştirmektedir.

Dijitalleşme aynı zamanda kendi kültürünü oluşturmuştur: dijital kültür... Dijital kültür, dijital medya araçlarıyla meydana getirilen yaratıcı bir süreç ve bir dizi üründür (Dijk, 2018, s. 323). Ekranların günümüzde her an her yerde kişilerin karşısına çıkıyor olması dijital bir kültürün oluşumunu sağlamaktadır. Çalışmaya konu olan platformlar, dijital kültürün yaygınlaşmasının bir sonucu olarak bireylerin yaşamında konumlanmaktadır. Ağ toplumunda ekranlar her yerdedir (Dijk, 2018, s. 298) ve bireyler günlük planlarını ekran izleme alışkanlıklarına göre şekillendirmektedirler.

Kullanımlar ve doyumlar kuramı iletişim alanındaki gelişmelerin etkisiyle tarihsel süreç içerisinde çeşitli aşamalardan geçmiş ve kuramdan faydalanan veya katkı sağlayan uzmanların çalışmalarını yoğunlaştırdığı alanlar dönemlere göre farklılıklar göstermiştir. Kuram çerçevesinde yarım asrı aşkın süre televizyon, radyo, gazete ve dergi gibi geleneksel kitle iletişim araçları üzerine çalışmalar yapılmıştır. Ancak 2000’li yılların 
başından itibaren dijitalleşmenin iletişim alanına getirdiği yenilikler ve oluşturduğu yeni mecralar uzmanları dijital ortamlardaki doyumları araştırmaya yönlendirmiştir. Dijitalleşmenin medyada meydana getirdiği köklü değişikliklerin başında şüphesiz "yeni medya" başlığında kavramsallaştırılan mecralar gelmektedir. Özellikle son yıllarda yeni medya alanına ilişkin yapılan çok sayıda araştırma kullanıcıların söz konusu mecralardaki kullanım davranışlarını ve doyumlarını ölçmeye yöneliktir. Kullanımlar ve doyumlar kuramının Ustakara ve Cevher'in (2019, s. 818-819) belirttiği gibi Instagram, Twitter ve Snapchat gibi sosyal medya mecralarındaki doyumları tespit etmede hangi derecede etkili olduğu çeşitli araştırmacılar tarafından çalışılmış ve olumlu sonuçlar alınmıştır. Dijitalleşmenin iletişim teknolojilerinde meydana getirdiği önemli yeniliklerden biri çeşitli aşamalardan geçerek günümüzdeki haline ulaşan dijital platformlardır. Geleneksel televizyon yayıncıllğının dijital platformlara taşınması ve bireylerin izleme alışkanlıklarının yeniden şekillenmesini beraberinde getirmiştir. Söz konusu durum izleyici araştırmalarının dijital platformlar özelinde yoğunlaşması sonucunu doğurmuştur. Dijital platformların izleme dinamikleri göz önünde bulundurulduğunda kullanımlar ve doyumlar kuramı bu platformların tercih sebeplerinin tespit edilmesinde, izleme alışkanlıklarını şekillendiren dinamiklerin aydınlatılmasında işlevsel bir rol oynamaktadır. Söz konusu durum bu çalışmada kullanımlar ve doyumlar kuramının baz alınmasında önemli rol oynamaktadır.

\section{Dijital Platformlar}

Televizyon yayıncılığının icra ediliş biçimi (teknik ve içerik bakımından) tarihsel süreç içerisinde teknolojinin gelişimi ile değişikliklere uğrayarak günümüzdeki şeklini almıştır. Televizyon yayıncılığı en önemli kırılma noktalarından birini uydu teknolojisinin gelişimi ile yaşamıştır.

1962 yılında uzaya gönderilen Telstar1 uydusu yardımıyla Fransa'dan ABD’ye ilk televizyon yayını yapılmış ve 1965 yılında Intelsat (International Satellite System) adı verilen kıtalar arası haberleşme sistemi ABD'de kurulmuştur (Akyol, 2012, s. 24). 1962'den günümüze binden fazla uydu uzaya gönderilmiştir. Türkiye ilk uydusu TÜRKSAT 1-B'yi Fransa iş birliğiyle 1994'te uzaya göndermiştir. İlk uyduyu TÜRKSAT 1-C ve EURASIASAT 1-A takip etmiştir. 2001 yllında atılan EURASIASAT 1-A Türkiye'nin sayısal yayıncilık ve uydudan internet yayıncılığı uygulayabilmesine imkân vermesi açısından önem taşımaktadır.

Dijital platformların ortaya çıkışını hazırlayan ise sayısal yayıncılık teknolojisinin gelişimi olmuştur. Türkiye 2000’li yılları sayısal yayıncılık teknolojilerine yönelik adımlar atarak karşılamıştır. 1999 yılında Dijital TV anlaşması ile Digitürk'ün kurulması bu alanda atılan en önemli adımların başında gelmektedir. 2008 yılında TRT kablolu yayıncılığını sonlandırarak dijital yayıncılığa geçmiştir (Tanrı̈̈ver, 2011, s. 15).

Dijital yayıncllık sistemleri uydu yayıncılığı, IPTV (Internet Protocol Television), Web TV, HBB TV ve OTT TV şeklinde sınıflandırılabilmektedir. Çalışma kapsamında dijital platform örneklemi olarak seçilen Netflix, OTT TV örneklerinden olmaktadır. OTT, İngilizce’de "bir şeyin üzerinde” anlamına gelen Over-The-Top ifadesinin kısaltmasıdır. Dolayısıyla OTT TV, internet üzerinden sunulan televizyon hizmetleri anlamına gelmektedir. OTT, görüntülü içeriğin televizyonun yanı sıra başta bilgisayar olmak üzere çeşitli mobil cihazlardan izlenilmesine olanak tanımaktadır. OTT TV ilk bakışta Web TV ve IPTV ile benzerlik gösteriyor olsa da bir takım temel özellikleri açısından ayrılmaktadır. Web TV herhangi bir abonelik gerektirmeden bilgisayar üzerinden izlenen internet yayınlarını ifade ederken IPTV denetlenen özel bir ağ üzerinden yayınları ulaştırmaktadır. OTT TV ise kapalı bir ağa ihtiyaç duyan IPTV ile kıyaslandığında internete genişbant erişim ile bağlanan herkese sunulan bir hizmet olarak farklılaşmaktadır (Akyol, 2012, s. 62). Netflix, Hulu ve Amazon Prime günümüzdeki en yaygın OTT TV örneklerini oluşturmaktadır.

Çalışmaya konu olan 'dijital platformlar' olarak da adlandırılabilecek dijital yayın sistemleri çeşitli özellikler göstermektedir. Pay TV, Catch Up TV, Mobil TV, kişiselleştirme ve Video on Demand gibi özelliklere sahip olan dijital platformlar teknolojik gelişmelerden en çok etkilenen alanların başında gelmektedir. 
Türkiye, yeni nesil olarak adlandırılabilecek dijital platformlar alanında son yıllarda önemli adımların atıldığı bir yer olarak öne çıkmaktadır. Puhutv ve BluTV gibi yerel markaların faaliyet gösteriyor olmasının yanı sıra çalışmaya konu olan uluslararası dijital platform Netflix, ülkemizde Netflix Türkiye adıyla faaliyet göstermektedir. Ayrıca Hulu, DC Universe, Amazon Prime Video, Youtube Premium ve CBS All Access uluslararası dijital platformlar olarak öne çıkmaktadır. Netflix'in gerek bu çalışmaya konu olması gerek uluslararası alandaki etkisi ve yaygınlığı bakımından kuruluş bilgileri ile gelişim aşamalarına değinmek faydalı olacaktır.

ABD merkezli uluslararası hizmet veren Netflix şirketi 1997 yılında kurulmuştur. DVD satışı ve kiralama hizmeti ekseninde temeli atılan şirket kuruluşundan yaklaşık bir yıl sonra DVD satışlarını durdurarak posta yoluyla kiralama üzerine çalışmalarını yoğunlaştırmış ve iş modelini kısmen yeniden şekillendirmiştir. Bunun sonucu olarak 1999'da aylık abonelik sistemini tanıtmasının ardından 2007 yılının şubat ayına kadar söz konusu sistem dâhilinde hizmet vermeye devam etmiştir. 1999-2007 yılları arasındaki aylık abonelik sistem "sınırsız DVD kiralama" üzerine kurulmuştur. Aboneler ayda 19,95 dolar ödeyerek dört DVD kiralayabilmişlerdir.

2007 yılı Netflix şirketi için bir dönüm noktası olmuştur. Günümüzde Netflix denildiğinde akla gelen sistem ve izleme deneyiminin bu yıl itibarıyla temellendirildiği görülmektedir. Şirket internet üzerinden yayın hizmeti vermeye başlayarak altı ve on sekiz saatlik iki tarife belirlemiştir. Abonelerden altı saatlik hizmeti için aylık 5,99 dolar, on sekiz saatlik yayınlar için 17,99 dolar ücret talep edilmiştir.

Günümüzde “yeni medya” başlı̆̆ında kavramsallaştırılan Youtube, Facebook, Twitter gibi sosyal ağların 2007 ve sonrasında yükselişe geçmesi özellikle yayıncılık alanındaki dijitalleşme sürecini hızlandırmıştır. Netflix bu bağlamda dijitalleşme çalışmalarına hız vererek 2008 yılında saat başına 1 dolar ek ücret ile sınırsız yayın hizmeti vermeye başlamıştır.

Şirket gelecek yıllardaki ekran çeşitliliğini ön görerek 2010 yılında Netflix İos, 2011 yllında Android uygulamasını yayınladı. 2010 yılında Kanada'da hizmet vermeye başlayan Netflix için 2011 yılı uluslararası alanda genişlemeye yönelik önemli adımların atıldığı bir yıl olmuştur. Brezilya, Arjantin, Uruguay, Paraguay, Bolivya, Şili, Meksika, Peru, Ekvador ve Karayipler'de faaliyet göstermeye başlayan şirket 2012 yllında ise İngiltere ve İrlanda öncelikli olmak üzere Avrupa pazarına giriş yapmıştır.

Netflix orijinal içerik üretimine yönelik ilk adımını 2013 yılının şubat ayında atmıştır. İlk orijinal içeriği olan House of Cards dizisinin tüm bölümlerini aynı anda yayınlayan şirket çoklu profil oluşturma özelliğini de devreye sokmuştur. İzlenilenlerin paylaşılması imkânını doğuran bu adım Netflix’in yayılması için de önemli bir aşama teşkil etmiştir. Sezonun tüm bölümlerinin aynı anda yayına girmesi ile Netflix dizi maratonu (binge watching) kavramını da izleyicilere kazandırmıştır (Akkuş, 2019, s.179).

2015 yılında Epix ile olan anlaşmasını sonlandıran Netflix, orijinal içerik üretimine ağırlık vererek kendi içerik dünyasını oluşturmaya başlamıştır. 2016 yılında çocuklar için özel içerik eklenmesinin yanı sıra Univision Communications Inc. ile anlaşarak Narcos’u İspanyolca dilinde yayınlamıştır. Böylece İngilizce dışındaki dilleri konuşanlara hitap eden içerikler de Netflix içerisinde yer almaya başlamış ve şirketin uluslararasılaşma süreci yeni bir aşamaya geçmiştir. Takip eden yıllarda İspanyolca orijinal içeriklerin sayısı artmış ve Almanca dâhil çeşitli dillerde orijinal içerikler üretilmiştir.

91. Oscar Ödülleri’nde Roma filmi Netflix’e "En İyi Yönetmen”, “En İyi Görüntü Yönetmeni” ve "Yabancı Dilde En İyi Film” olmak üzere üç dalda ödül kazandırmıştır. Netflix, günümüzde 190'dan fazla ülkede hizmet vermektedir.

Netflix’in hizmet verdiği ülkelerden biri Türkiye'dir. Netflix Türkiye adıyla hizmet veren platform Türkiye'ye yönelik içerik çalışmaları yürütmektedir. Türkiye’ye özel ürettiği ilk içerik olan "Hakan: Muhafız" adlı yapımı 
14 Aralık 2018 tarihinde abonelerine sunmuştur. Türkiye’yi önemsediklerini her fırsatta belirten şirket, Türkçe yapım çalışmalarını sürdürmektedir.

Netflix Türkiye, 2019 yılının Eylül ayında yaptığı açılamada Türkiye içerisinde 1.5 milyon tekil kullanıcısı olduğunu belirtmiştir. Tekil kullanıcılarda bulunan aile hesapları da göz önünde bulundurulduğunda yaklaşık rakam dört milyon olarak belirmektedir. Netflix’in Türkiye sınırları içerisinde kısa denebilecek sürede ulaştı̆̆ 1 tekil kullanıcı rakamı önemli bir başarı olarak değerlendirilmektedir.

Netflix Türkiye'de üç farklı üyelik sistemi bulunmaktadır (www.netflix.com.tr): Temel plan (17.99 TL), standart plan (29.99 TL) ve özel plan (41.00 TL). 2019 yılının Eylül ayında yürürlüğe giren yönetmelik gereğince Radyo Televizyon Üst Kurulu (RTÜK), dijital platformlardan kullanıcı başına gelirden \% 0.5 pay alacaktır. Söz konusu durumun Netflix'in ve ülkede faaliyet gösteren diğer dijital platformların ücret politikasına nasıl etki edeceği yakın gelecekte netlik kazanacaktır.

Radyo Televizyon Üst Kurulu'nun (RTÜK) 1 Ağustos 2019 tarihinde Resmî Gazete'de yayımlanan ve 2 Eylül 2019 'da yürürlüğe giren yönetmeliği gereğince internet üzerinden yayın yapan platformlara lisans zorunluluğu getirilmiştir. Yönetmelik gereği internet ortamından yayın iletim yetkilendirme ücreti yıllık 100 bin TL olarak uygulanmaktadır. Yıllık gelirlerinin binde 5'ini her yıl RTÜK'e verecek olan yayıncı kuruluşların denetime tabi tutulacağı belirtilmiştir ancak söz konusu denetimin hangi şekilde gerçekleşeceği yakın gelecekteki uygulamalar sonucu netleşecektir.

Netflix günümüzde geldiği noktada yeni dünyanın izleyici profilinin şekillenmesinde etkili olmuştur. Dünyanın çeşitli ülkelerinde üretilen içeriklerin yer aldığı bir platform olması izleyiciye ulusötesi bir nitelik kazandırmıştır (Jenner, 2018, s.241). Hindistan'da Netflix’e erişim sağlayan bir izleyici Amerikan, İngiliz ve İspanyol yapımı içeriklerden istediğini izleyebilmektedir.

\section{Amaç ve Yöntem}

Bireylerin kitle iletişim araçlarını kullanmalarının altında yatan güdüleri keşfetmek Kullanımlar ve Doyumlar yaklaşımının temel amaçları arasında yer almaktadır (Özçetin, 2018, s. 114). Yazılı materyal temelinde başlayan ve gazete-dergi yapısında şekillenen kitle iletişimi tarihsel süreç içerisinde sesin ve görüntünün aktarılmasına dayalı bilimsel çalışmaların ilerlemesinin bir sonucu olarak radyo ve televizyon biçiminde işitsel-görsel bir hal almıştır. 1960'ların sonlarına doğru başlayan internet çalışmaları 1980'lerde hızlanan küreselleşmeyle birlikte geliştirilmiş ve internet 1990'larda halkın kullanımına sunulmuştur. Söz konusu durum başta iletişim teknolojileri olmak üzere çeşitli alanlarda dijitalleşme sürecini hızlandırmıştır. Kitle iletişim araçları dijitalleşme sürecinden önemli ölçüde etkilenerek iletişim ve internet teknolojilerindeki yakınsamanın (convergence) da etkisiyle günümüzdeki şeklini almıştır. Televizyon; tarih sahnesinde belirdiği dönemden günümüze teknolojik gelişmelere bağlı değişimlerin önemli odak noktalarından olmakta ve internetin yaygın gücüne rağmen etki alanını korumaya devam etmektedir. Teknoloji ürünü bir cihaz olmasının ötesinde ekonomik, politik, kültürel ve sosyolojik araştırmalara konu olan televizyon her dönem izleyicisi ile birlikte değerlendirilmiştir. 1990’lı yıllarda (günümüzden değerlendirildiğinde 'geleneksel' olarak nitelendirilebilecek) platformlara taşınan televizyon yayınları günümüzde dijitalleşen platformlarda varlığını sürdürmektedir. Yayıncılığın dijital platformlara taşınmasıyla içerikte meydana gelen değişim çalışmanın ilgili bölümlerinde ele alınmıştır. Dijitalleşme ile birlikte televizyon yayıncılığına dair değişen noktalar teknik ve içerikle sınırlı kalmamıştır. Televizyon izleyicisi de dijitalleşme sürecinde beklenti, istek ve izleme deneyimi açısından yeniden konumlanmıştır.

$\mathrm{Bu}$ çalışmanın genel amacı dijital platform kullanıcılarının izleme alışkanlıklarının belirlenmesidir. Alışkanlıklar ve tercih nedenlerinin ortaya konulmasının ardından kullanımlar ve doyumlar yaklaşımının aktif izleyici tanımlaması çerçevesinde izleyicinin aktifliği tartışlacaktır. Bu bağlamda uluslararası dijital 
platformlar arasında Türkiye'de resmi olarak ilk faaliyet gösteren Netflix platformu kullanıcılarına izleme alışkanlıklarını, tercih nedenlerini ve geleneksel televizyon yayıncılığı ile dijital platformda yaşadıkları izleme deneyimini karşılaştırmaya yönelik sorular yöneltilmiştir.

Çalışma kapsamında aşağıda belirtilen sorulara yanıt aranmaktadır:

- Bireylerin izleme alışkanlıkları onların aktif izleyici konumunu nasıl etkilemektedir?

- Dijital çağın sunduğu araç çeşitliliği (telefon, tablet, taşınabilir bilgisayar vb.) izleme alışkanlıkları üzerinde etkili midir?

- Yapımlardaki içerik seçimi, içerik çeşitliliği ve kültürel unsurlar izleme alışkanlıkları üzerinde etkili midir?

Ayrıca günümüzdeki izleyici tercihlerinin televizyon yayıncılığının dijital platformlardaki geleceğine ilişkin kalıcılığını irdeleme ve konuya dair ön görülerde bulunulmasını sağlayacak sorular da çalışma kapsamında yer almaktadır. Netflix'in yaygın uluslararası dijital platformlar arasında Türkiye'de faaliyet gösteren ilk platform olması çalışmaya konu olmasının başlıca sebebini oluşturmaktadır. Dijital platform kullanıcılarının izleme alışkanlıklarının şekillenmesinde söz konusu platformların kullanım biçimlerinin, kişiselleştirilmiş hizmetlerinin etkili olması bu çalışmanın hipotezini oluşturmaktadır. Geleneksel televizyon yayıncılığında içeriğe "ulaşma" veya başka bir ifade biçimiyle "maruz kalma" durumu söz konusu iken dijital platformlarda yer alan türe göre içerik seçimi özgürlüğü, çoklu dilde ses-altyazı seçenekleri, izleme geçmişini referans alan bir algoritma yapısının benzer türde izleme önerileri sunması gibi hizmetler kullanıcılara kayda değer ölçüde konforlu bir izleme deneyimi sunmakta ve genel izleme alışkanlığının bu kriterler doğrultusunda şekillenmesini sağlamaktadır. Çalışma hipotezinin çıkış noktasını dijital platformlardaki bu tür referanslar oluşturmaktadır.

Çalışmada "Amaca Göre Örnekleme (Purposive Sampling)" tekniği kullanılarak nicel araştırma gerçekleştirilmiştir (Thompson, 1997). Nicel araştırmada özel bir örneklem olarak Netflix kullanıcısı kitle üzerinde uygulanmıştır. Verilerin toplanması aşamasında online veri toplama tekniklerinden Bilgisayar Destekli İnternet Anketi (CAWI) tercih edilmiş ve veriler tam yapılandırılmış soru formu kullanılarak elde edilmiştir.

Anket, birincil kaynaklardan bilgi toplamak için hazırlanan sistematik bir soru formudur ve amacı araştırmanın problemini çözecek ve ele alınan hipotezleri test edecek bilgileri sistematik bir şekilde toplayarak saklamaktır (İslamoğlu ve Alnıaçık, 2013, s. 129).

Hazırlanış biçimine göre soru formu, görüşme cetveli ve görüşme kılavuzu olmak üzere üç farklı isim alan anket yönteminde bu çalışma için soru formu biçimi kullanılmıştır. Soru formu cevaplayıcıya başkaca soru sormayı gerektirmeyecek ve ihtiyaç duyulan tüm bilgileri verecek biçimde düzenlenmiş ve anketörle cevaplayıcı karşı karşıya görüşecekse buna görüşme cetveli denir. Soru formu ise görüşme cetvelinin anketör olmaksızın uygulanışıdır (Keleş’ten akt. İslamoğlu ve Alnıaçık, 2013, s. 129).

Uygulanış biçimine göre yüz yüze görüşme, telefonla görüşme, posta ile gönderme ve internetle anket olarak dört başlıkta çeşitlendirilen anket yönteminde (İslamoğlu ve Alnıaçık, 2013, s. 130) bu çalışma için internet üstünden anket uygulaması yapılmıştır. Sorular elektronik posta ve sosyal ağlar aracıllğıyla katılımcılara ulaştırılmıştır. Hızlı bilgi toplama ve anketör kullanılmadığından anketörün hatalı tutumundan etkilenmeme kriterlerinin (İslamoğlu ve Alnıçık, 2013, s. 132) göz önünde bulundurulması bu uygulama biçiminin seçilmesinde etkili olmuştur.

Soru formunda yer alan sorular araştırmanın hipotezi ile ilişkili olacak şekilde belirlenmiştir. İslamoğlu ve Alnıaçık'ın (2013, s. 135) belirttiği açıklık ilkesi gereği hazırlanış aşamasında soruların amaca hizmet etmesi, herkes tarafından aynı anlamda anlaşılması ve cümlelerin basit sözcüklerle teknik dilden uzak olması esas alınmıştır. 
Soru formunda çoktan seçmeli sorular, iki cevaplı sorular ve dereceleme soruları yer almıştır. Birden çok soru çeşidinin kullanılmasındaki temel amaç soru formunun tutarlılığı ile araştırmanın genelinin güvenilirliğinin sağlanmasıdır.

Hazırlanan soru formunda katılımcılara öncelikle geleneksel televizyon yayınlarını izleme alışkanlıkları (program tercihleri ve izleme sıklığı), dijital platformların bilinirlikleri ve hangilerinin kullanıldığına dair sorular yöneltilmiştir. Soru formunun devamında çalışmanın dijital platformları temsil bazında örneklemi olan Netflix’e yönelik üyelik durumu, izleme sıklı̆̆ı, izleme alışkanlıkları, tercih edilme sebepleri ve Netflix özelinden yola çıkarak dijital platformların gelecekteki konumuna dair öngörülerde bulunmaya imkân sağlayan sorular yer almıştır. Soruların hazırlanmasında bu sıranın izlenmesinin nedenini araştırma kapsaminda cevap aranan;

- Bireylerin izleme alışkanlıkları onların aktif izleyici konumunu nasıl etkilemektedir?

- Dijital çağın sunduğu araç çeşitliliği (telefon, tablet, taşınabilir bilgisayar vb.) izleme alışkanlıkları üzerinde etkili midir?

- Yapımlardaki içerik seçimi, içerik çeşitliliği ve kültürel unsurlar izleme alışkanlıkları üzerinde etkili midir?

soruların göz önünde bulundurulması olmuştur.

Kullanımlar ve doyumlar yaklaşımının kitle iletişim araçları kullanımının altında yatan güdüleri keşfetme (Özçetin, 2018, s. 114) amacı araştırma soruları hazırlanırken göz önünde bulundurulmuştur. "Netflix’in aşağıdaki özelliklerinden hangisi sizin için bir tercih sebebidir?” sorusunun devamında katılımcılara aşağıdaki ifadelere katılım düzeyleri sorulmuştur:

- Netflix içeriklerinin mobil cihazlara indirilebilmesi ve internet olmayan ortamlarda da izlenilebilir olmaları tercih etmemde önemli bir sebeptir.

- Yapımların kalitesi Netflix’i tercih etmemde önemli bir sebeptir.

- İçerik seçimi özgürlüğü Netflix’i tercih etmemde önemli bir sebeptir.

- İçerik çeşitliliği (suç, komedi, romantik vb.) Netflix’i tercih etmemde önemli bir sebeptir.

- Yaşadığım ülkenin kültürünü ve dilini içeren yapımların yer alması beni Netflix kullanmaya yönlendirebilir.

- Netflix’te izlediğim içeriğin farklı bir kültürü (Batı, Amerikan vb.) temsil etmesi benim için tercih sebebidir.

- Reklamsız izleme Netflix’i tercih etmemde önemli bir sebeptir.

Yukarıdaki ifadelerin belirlenmesinde çalışmanın hipotezi esas alınmıştır. Kullanımlar ve doyumlar yaklaşımının kitle iletişim araçları kullanımının altında yatan güdüleri keşfetme (Özçetin, 2018, s. 114) özelliği ile bireyin gereksinimlerinin tatmin edilmesi gerekliliği (Mutlu, 2005, s. 352) görüşü çalışmanın "dijital platform kullanıcılarının izleme alışkanlıklarının şekillenmesinde söz konusu platformların kullanım biçimlerinin, kişiselleştirilmiş hizmetlerinin etkili olduğu" hipotezinin araştırılması için uygun bir çıkış noktası ve perspektif teşkil etmektedir.

319'u kadın $(\% 50,2)$ ve 317'si $(\% 49,8)$ erkek olmak üzere toplam 636 katılımcı soru formunu yanıtlamıştır. Formda katılımcılara dair temel bilgilerden cinsiyet, yaş aralığı, eğitim durumu ve meslek dâhil olmak üzere 33 soru yöneltilmiştir. Çalışmanın örneklemi olan Netflix platformunun kullanımına yönelik soruya 393 $(\% 61,8)$ katılımcı olumlu yanıt vermiştir. Çalışmanın Bulgular ile Tartışma-Sonuç bölümünde söz konusu soruya olumlu yanıt veren 385 kişinin cevapları esas alınacaktır. 
Araştırmadan elde edilen veriler "tanımlayıcı istatistik (descriptive statistics)" analizlerine tabi tutulmuş (Gürsakal, 2015), sonuçların değerlendirilmesinde frekans ve oran değerleri dikkate alınıp ortalama varyans gibi özetleyici tahminlerden faydalanılmıştır.

\section{Bulgular}

Dijital platform kullanıcılarının izleme alışkanlıklarının belirlenmesinin amaçlandığı bu çalışmada anket yönteminden yararlanılarak veriler toplanmıştır. Katılımcılara izleme alışkanlıklarının belirlenmesinde etkili olan unsurları saptamaya yönelik sorular yöneltilmiştir. Bu doğrultuda elde edilen bulgular aşağıda yer almaktadır. Bulguların değerlendirilmesinde soru formunu cevaplayan 636 kişiden "Netflix kullanıyor musunuz?” sorusuna olumlu yanıt veren 385 katılımcı esas alınmıştır.

\section{Geleneksel Televizyon Yayınlarını İzleme Alışkanlıkları}

Katılımcılara "Televizyonda aşağıdakilerden hangisini izliyorsunuz?" sorusuna şıklarda "dizi, film, belgesel, haber programı, reality şov ve diğer" seçeneklerinde tekli veya birden fazla işaretleme yaparak yanıt vermeleri istenmiştir. Verilen yanıtlardaki dağılım dikkat çekmektedir. Katılımcıların \% 10,6'sı ( 41 kişi) dizi, \% 7,26'sı (28 kişi) haber programı, \% 5,19’u (20) belgesel, \% 4,41’i (17 kişi) film ve \%0,77’si (3 kişi) reality şov yanıtını vermiştir. Söz konusu cevaplar katılımcıların \% 28,23'ünü (109 kişi) oluşturmaktadır. Geriye kalan 276 katılımcı $(\% 71,77)$ söz konusu soruya birden fazla şık işaretleyerek cevap vermiştir. Bunlardan \% 14 'ü (54 kişi) dizi, film, belgesel ve haber programı şıklarını bir arada işaretlemiştir. Şıklardaki tüm içerik türlerini bir arada izlediğini belirtenler ise \% 10,38'i (40 kişi) oluşturmaktadır. Bu noktada dikkat çeken ise çalışmanın takip eden bölümünde Netflix kullanıcılarının içerik tercihlerine ilişkin rakamlar incelendiğinde ortaya çıkmaktadır. Gerek geleneksel televizyon yayını içeriklerinde gerek ise Netflix içeriklerinde tercih konusunda dizilerin ilk sırada olduğu görülmektedir. Ancak rakamsal dağılım arasındaki fark oldukça yüksektir: Geleneksel televizyonda dizi izleme yüzdesi 10,06 iken dijital platform olan Netflix’te yüzde 85 olarak görülmektedir. Netflix'in geleneksel mecralarda yayınlananlardan çok kendi ürettiği orijinal içerikleri yayınlayan bir platform stratejisi izlediği göz önünde bulundurulduğunda izleyicinin dijital platformlara yönelmesinde ve platformda reality şov, belgesel, film ve konser gibi çeşitli türlerden içerikler yer aldığı halde yüzde 80 gibi yüksek bir oranda dizileri tercih ediyor olması söz konusu platformların izleyici dönüşümü üzerindeki etkisini de ortaya koymaktadır.

Geleneksel televizyon yayını içeriklerini günlük ve haftalık izleme sıklığına yönelik soruya katılımcıların \% 45,19’u (174 kişi) "günde 1 saatten az” yanıtını vermiştir. Katılımcıların \% 26,23'ü (101 kişi) günde 1-3 saat arası, \% 7,53'ü (29 kişi) günde 3-5 saat arası ve yüzde 1,29’u (5 kişi) ise günde 5 saat ve üzeri televizyon izlediklerini belirtmişlerdir. Katılımcıların bir bölümü ise doğrudan haftalık izleme sıklığına yönelik yanıt vermeyi tercih etmiştir. Haftada 1 saatten az televizyon izlediğini belirtenler \% 9,09'u (35 kişi) oluştururken \% 5,45 (21 kişi) haftada 1-3 saat arası, \% 4,41 (17 kişi) 3-5 saat arası ve \% 0,77 (3 kişi) 5 saat ve üzeri yanıtını vermişlerdir.

\section{Netflix İçeriklerini İzleme Alışkanlıkları}

Netflix içerik çeşitliliğiyle dikkat çeken bir dijital platform olarak ön plana çıkmaktadır. Bu bağlamda katılımcılardan ağırlıklı olarak izledikleri ilk üç kategoriyi işaretlemeleri istenmiştir. Katılımcıların \% 85’i diziler, \% 71,4'ü Netflix orijinal içerikleri ve \% 35,4'ü ise belgeseller cevabını vermişlerdir.

Netflix’te yer alan içerikleri günlük ve haftalık izleme sıklığına yönelik soruya katılımcıların \% 43,89’u (169) kişi "günde 1-3 saat arası” yanıtını vermiştir. Katılımcıların \% 12,98’i (50 kişi) günde 1 saatten az, \% 10,64'ü (41 kişi) günde 3-5 saat arası, \% 4,15’i (16 kişi) ise günde 5 saat ve üzeri izlediklerini belirtmişlerdir. Haftalık izleme sıklığına ilişkin yanıt veren kullanıcıların \% 11,16’sı (43 kişi) haftada 3-5 saat arası, \% 7,27'si (28 kişi) 
haftada 1-3 saat arası, \% 6,75’i (26 kişi) haftada 5 saat ve üzeri ve \% 3,11’i (12 kişi) haftada 1 saatten az izlediğini belirtmiştir.

\section{İçeriklere Erişimde Kullanılan Cihazlar}

"Geleneksel televizyon yayın içeriklerini ağırlıklı olarak hangi cihazdan izliyorsunuz?" sorusuna katılımcıların \% 49,35’i (190 kişi) televizyon yanıtını vermiştir. Katılımcıların \% 20’si (77 kişi) bilgisayar, \% 17,40’ı (67 kişi) akıllı telefon, \% 11,68’i (45 kişi) akıllı televizyon ve yüzde 1,55’i (6 kişi) tablet kullanarak geleneksel televizyon yayın içeriklerini izlediklerini belirtmişlerdir.

"Netflix’i ağırlıklı olarak hangi cihaz yoluyla kullanıyorsunuz?" sorusuna ise katılımcıların \% 34,54'ü (133 kişi) bilgisayar, \% 31,68’i (122 kişi) akıllı televizyon, \% 29,87’si (115 kişi) akıllı telefon ve \% 3,63’ü (14 kişi) tablet yanıtını vermiştir.

Akıllı televizyon, bilgisayar ve akıllı telefon gibi mobil teknolojinin gelişmiş olduğu cihazlardan içeriklere erişimin izleyiciler nezdindeki önemini daha net kavrayabilmek ve soru formundaki soruların kendi aralarındaki tutarlılı̆ıını güçlendirmek adına katılımcılardan söz konusu iki soruya ek olarak "Dijital platformların akıllı televizyonlar dâhil olmak üzere akıllı telefon ve tablet gibi mobil cihazlarda erişilebiliyor olması tercih edilmelerinde önemli bir sebeptir." ifadesine katılım düzeyini ölçen yanıt vermeleri istenmiştir. Katılımcıların \%74,02'si (285 kişi) “kesinlikle katılıyorum”, \%21,81'i “katılıyorum”, \%0,25’i (1 kişi) “kesinlikle katılmıyorum", \% 1,29'u (5 kişi) "katılmıyorum” yanıtını verirken \% 2,07 (8 kişi) ise kararsı olduğunu belirtmiştir. 2 katılımcı görüş belirtmemiştir.

\section{Netflix'in Tercih Sebepleri Üzerine}

Çalışmanın amacı gereği izleyicilerin dönüşümünde dijital platformların etkisini saptayabilmek adına söz konusu platformların tercih sebepleri üzerinde durmak faydalı olacaktır. Bu bağlamda soru formunda yer alan “Netflix’in aşağıdaki özelliklerinden hangisi sizin için bir tercih sebebidir?” sorusuna katılımcıların \% 44’ü (171 kişi) orijinal içeriklere sahip olması, \% 14,28’i (55 kişi) içeriğin platform tekrar açıldıktan sonra kaldığı yerden devam etmesi, \% 11,68'i içeriklerin detaylı kategorilere ayrılmış olması, \% 8,83'ü istenilen bölümün izlenebilmesi, \% 7,27’si (28 kişi) seçimleriniz doğrultusunda tavsiyelerde bulunması ve \% 3,63' ü (14 kişi) izleme listesi oluşturulabilmesi yanıtını vermiştir. Toplam 347 kişinin verdiği yanıtlara ek olarak "diğer" seçeneğine yazan 38 (\% 9,87) kişi ise çoklu altyazı ve dublaj, zengin içerik kütüphanesi, reklamsız izleme ve içerik indirerek internetsiz ortamda izleme gibi tercih sebepleri belirtmişlerdir.

Soru formuna verilen cevapların ve çalışmanın güvenilirliğinin sağlanması açısından tercih sebeplerine yönelik katılımcılara derecelemeli sorular sorulmuştur. "Netflix içeriklerinin mobil cihazlara indirilebilmesi ve internet olmayan ortamlarda da izlenilebilir olmaları tercih etmemde önemli bir sebeptir." ifadesine verilen yanıtlar \% 63,37 (244 kişi) kesin katılıyorum, \% 23,37 (90 kişi) katılıyorum, \% 2,07 (8 kişi) kesin katılmıyorum, \% 5,97 (23 kişi) katılmıyorum ve \% 3,89 (15 kişi) kararsızım şeklinde olmuştur. 5 (\% 1,29) katılımcı söz konusu soruya yanıt vermemiştir.

"Yapımların kalitesi Netflix’i tercih etmemde önemli bir sebeptir." ifadesine katılımcıların \% 59,22'si (228 kişi) kesinlikle katılıyorum, \% 31,16’sı (120 kişi) katılıyorum, \% 1,55’i (6 kişi) kesinlikle katılmıyorum, \% 2,85’i katılmıyorum ve \% 4,67’si (18 kişi) kararsızım yanıtını vermiştir. 2 ( \% 0,51) katılımcı söz konusu soruya yanıt vermemiştir.

“İçerik seçimi özgürlüğü Netflix’i tercih etmemde önemli bir sebeptir.” ifadesine katılımcıların \% 61,29’u (236 kişi) kesin katılıyorum, \% 29,87'si (115 kişi) katılıyorum, \% 0,77'si (3 kişi) kesin katılmıyorum, \% 2,59'u (10 kişi) katılmıyorum, \% 4,41 (17 kişi) kararsızım yanıtını vermiştir. 4 katılımcı (\% 1,03) söz konusu soruya yanıt vermemiştir. 
"İçerik çeşitliliği (suç, komedi, romantik vb.) Netflix’i tercih etmemde önemli bir sebeptir." ifadesine katılımcıların \% 59,48’i (229 kişi) kesin katılıyorum, \% 30,64'ü (118 kişi) katılıyorum, \% 1,29’u (5 kişi) kesin katılmıyorum, \% 2,85'i (11 kişi) katılmıyorum ve \% 4,41’i (17 kişi) kararsızım yanıtını vermiştir. 5 katılımcı (\% 1,29) söz konusu soruya yanıt vermemiştir.

"Yaşadığım ülkenin kültürünü ve dilini içeren yapımların yer alması beni Netflix kullanmaya yönlendirebilir." ifadesine katılımcıların \% 29,61’i (114 kişi) katılıyorum, \% 29,35’i (113 kişi) katılmıyorum, \% 23,89’u (92 kişi) kesinlikle katılıyorum, \% 11,94'ü (46 kişi) kararsızım ve \% 3,89’u (15 kişi) kesinlikle katılmıyorum yanıtını vermiştir. 5 katılımcı $(\%$ 1,29) söz konusu soruya yanıt vermemiştir.

"Netflix’te izlediğim içeriğin farklı bir kültürü (Batı, Amerikan vb.) temsil etmesi benim için tercih sebebidir." İfadesine katılımcıların \% 17,40’1 (67 kişi) kesinlikle katılıyorum, \% 37,92'si katılıyorum, \% 3,37'si (13 kişi) kesinlikle katılmıyorum, \% 27,01'i (104 kişi) katılmıyorum, \% 12,20’si (47 kişi) kararsızım yanıtını vermiştir. 8 katılımcı $(\% 2,46)$ söz konusu soruya yanıt vermemiştir.

Dijital platformların en dikkat çeken özelliklerinin başında yayınların reklamlar yoluyla bölünmemesi gelmektedir. Bu bağlamda katılımcilara "Reklamsız izleme Netflix’i tercih etmemde önemli bir sebeptir." ifadesine katılım sorulmuştur. Katılımcıların \% 79,22'si (305 kişi) kesinlikle katılıyorum, \% 16,10'u (62 kişi) katıllyorum, \% 1,29'u (5 kişi) kesinlikle katılmıyorum, \% 0,77’si (3 kişi) katılmıorum, \% 1,55’i (6 kişi) kararsızım yanıtını vermiştir. 4 katılımcı $(\% 1,03)$ ise katılım derecesi belirtmemiştir.

\section{Özellikler Bakımından Geleneksel Televizyon Yayıncılığı ve Netflix Karşılaştırması}

Her biri aynı zamanda birer Netflix kullanıcısı/izleyicisi olan katılımcılara şıklarda verilen niteliklerden hangilerinin geleneksel televizyon yayıncılığına ve Netflix yapısına uygun olduğu sorulmuştur.

“Aşağıdaki ifadelerden hangisi Netflix için uygundur?” sorusuna katılımcılar birbirine yakın cevaplar vermişlerdir. Katılımcıların \%21,81 (84 kişi) yenilikçi, \%21,55’i (83 kişi) çeşitli, \%21,03’ü (81 kişi) kaliteli, \%15,06'sı (58 kişi) orijinal, \%9,61’i (37 kişi), \%8,05’i (31 kişi) erişilebilir ve \% 1,55’i (6 kişi) ise farklı yanıtını vermiştir. 5 katılımcı $(\% 1,29)$ söz konusu soruya yanıt vermemiştir.

“Aşağıdaki ifadelerden hangisi geleneksel televizyon yayıncılı̆̆ için uygundur?” sorusuna katılımcıların \%44,15'i (170 kişi) klasik, \%33,24'ü (128 kişi) eski moda, \%10,90'1 (42 kişi) erişilebilir, \%3,37’si (13 kişi) çeşitli, \%0,77'si (3 kişi) farklı, \%1,29'u (5 kişi) inovatif, \%1,03'ü (4 kişi) kaliteli, \% 1,29’u (5 kişi) orijinal, \% 2,07'si (8 kişi) yenilikçi yanıtını vermiştir. 7 katılımcı $(\% 1,81)$ ise söz konusu soruya yanıt vermemiştir.

\section{Dijital Platformların Geleceği}

Çalışma bağlamında Netflix özelinden yola çıkarak dijital platformların geleceğine dair ön görüler Sonuç ve Tartışma bölümünde ele alınacaktır. Söz konusu ön görülere temel teşkil etmesi bakımından katılımcılara farklı tiplerde (iki cevaplı, katılım dereceli) sorular yöneltilmiştir.

"Türk televizyonlarında takip ettiğim bir dizi ücretli bir dijital platforma geçtiği takdirde söz konusu diziyi izlemeye devam etmek için platforma üye olurum." ifadesine katılım derecesine yönelik verilen cevaplar dikkat çekici niteliktedir. Katılımcıların \%31,68’i (122 kişi) katılmıyorum, \%22,07’si (85 kişi) katılıyorum, \%13,24’ü (51 kişi) kesinlikle katılmıyorum, \%9,35’i (36 kişi) kesinlikle katılıyorum yanıtını verirken \%22,07’si (85 kişi) kararsız kaldığını belirtmiş̧ir. 6 katılımcı $(\% 1,55)$ ise söz konusu soruya yanıt vermemiştir.

"Vizyonda olan bir sinema filminin aynı anda Netflix'te yayınlanması durumunda" cümlesini katılımcıların \%71,68’i (276 kişi) “Netflix’te izlerim”, \%12,20’si (47 kişi) “sinema salonunda izlerim”, \%15,06’s (58 kişi) “her ikisinde de izlerim” şeklinde tamamlamıştır. 4 katılımcı $(\% 1,03)$ ise yanıt vermemiştir.

Geleneksel televizyon yayıncılığı ve Netflix seçenekleri verilerek "Yaşadığınız yerde ikisinden birini seçmek zorunda kalsaydınız tercihinizi hangisinden yana kullanırdınız?” sorusuna katılımcıların \%82,59’u (318 kişi) 
Netflix, \%15,58’i (60 kişi) geleneksel televizyon yayını yanıtını vermiştir. 7 katılımcı $(\% 1,81)$ ise söz konusu soruya yanıt vermemiştir.

“Netflix’i yakın çevrenize tavsiye eder misiniz?” sorusuna katılımcıların \%92,46’sı (356) evet, \%5,45’i (21 kişi) hayır yanıtını vermiştir. 8 katılımcı $(\% 2,46)$ söz konusu soruya yanıt vermemiştir.

“Televizyon yapımlarının yakın gelecekte yalnızca dijital platformlara taşınacağına inanıyorum.” ifadesine katılımcıların \%33,24’ü (128 kişi) kesinlikle katılıyorum, \%32,72’si (126 kişi) katılıyorum, \%17,14’ü (66 kişi) katılmıyorum, \% 3,37'si kesinlikle katılmıyorum, \% 12,20’si (47 kişi) kararsızım şeklinde yanıt vermişlerdir. 52 katılımcı $(\% 13,50)$ ise görüş belirtmemiştir.

\section{Tartışma ve Sonuç}

Dijital platformların uluslararası alanda olduğu gibi Türkiye'deki yükselişi çeşitli sonuçları beraberinde getirmektedir. Söz konusu sonuçlar hem yayıncilık sektörü hem de izleyiciler açısından gözlemlenebilmektedir. Yapımclar dijital platformlar ile iş birliği yoluna giderken izleyicilerin bu platformlara olan ilgisi giderek artış göstermektedir. Dijital platformların geleneksel yayın mecralarına kıyasla sunduğu esnek ve hatta konforlu denebilecek imkânlar izleyici alışkanlıklarını da etkilemektedir. Bu çalışmada dijital platform kullanıcılarının izleme alışkanlıkları ve tercih sebepleri araştırılmıştır.

Çalışmada günlük ve haftalık olarak saat bazında geleneksel televizyon yayınları ile Netflix izleme sıklığının dikkat çekici düzeyde farklı olduğu görülmektedir. Katılımcıların \%43,89’u günde 1-3 saat arası Netflix izlediklerini belirtirken \%26,23’ü 1-3 saat arasını geleneksel televizyon yayınlarına ayırdıklarını belirtmişlerdir. Haftalık izleme saatine dair veriler ise dijital platforma yönelimin ulaştığı noktayı belirginleştirmesi açısından önem taşımaktadır. Katılımcıların \%0,77'si haftada 5 saatten fazla televizyon izlediklerini belirtirken \%3,11'i ise Netflix izlediklerini belirtmişlerdir. Aradaki kayda değer fark dijital platformlara olan yönelimi belirginleştirmesi açısından önem taşımaktadır.

Çalışma kapsamında izleyicilerin geleneksel televizyon yayınlarına ve dijital platformlara erişim biçimleri irdelenmiştir. Netflix kullanıcılarının \%96,09'u bilgisayar, akıllı televizyon ve akıllı telefon ile içeriklere erişim sağlamaktadırlar. Aynı cihazlardan geleneksel televizyon yayınlarına erişim ise yüzde 50,63 oranında gerçekleşmektedir. Elde edilen bulgular ışığında bilgisayar ve mobil cihazlar yoluyla görüntülü içeriğe erişim eğiliminin yüksek olduğu sonucuna varılmıştır.

Netflix özelinde incelenen dijital platformların tercih sebepleri irdelendiğinde orijinal içeriklere sahip olunmasının başta gelen tercih sebebi olduğu sonucuna varılmaktadır. Çalışmaya konu olan dijital platform Netflix, yapımcılığını üstlendiği ve "Netflix Originals" adını verdiği içerikler yayınlamaktadır. Bu içerikler Netflix platformuna özel olmakta ve yalnızca aboneler tarafından izlenebilmektedir. Katılımcıların \%44’ünün orijinal içerikleri tercih sebebi olarak kabul etmesi içeriğin önemini de bir kez daha vurgulamaktadır. Kullanımlar ve doyumlar yaklaşımında belirtildiği üzere izleyicinin aktif ve isteklerine göre seçim yapan bireyler olduğu (Erdoğan ve Alemdar, 1990, s. 109) yargısı bu noktada bir kez daha doğrulanmaktadır.

İçerik seçimi özgürlüğünün ve çeşitliliğinin (suç, komedi, romantik vb.) izleyicilerin dijital platformlara yönelmesinde ve mevcut kullanıcıların izleyici sadakatini korumasında önemli bir unsur olduğu çalışmada varılan sonuçlar arasında yer almaktadır. Katılımcıların toplamda \%91,16’sı içerik seçiminin bir tercih unsuru olduğu ile ilgili soruya olumlu yanıt vermiştir. İçerik çeşitliliği ile ilgili soru ise katılımcıların \%90,12'si tarafından olumlu şekilde yanıtlanmıştır. Geleneksel televizyon yayıncılığında izleyicilerin içerik seçimi yalnızca kanal değiştirme eylemine bağlı iken dijital platformlarda bir özellik butonu olarak bulunması ve seçilen türe (suç, komedi, romantik, dram vb.) göre içerik listelenmesi izleyici üzerinde olumlu etki oluşturmakta ve izleme alışkanlığının bu doğrultuda şekillenmesi sonucunu doğurmaktadır. 
Günümüz küresel dünyasının en önemli kültür taşıyıcılarından biri olarak gösterilen televizyonun en önemli kaynaklarından biri popüler kültürdür (Cereci, 2016, s. 74). İçerik oluştururken başta popüler kültür olmak üzere ç̧şitli kültürel unsurları kullanan geleneksel televizyon yayıncıları ve dijital platformlar küresel ve yerel unsurlara ağırlık vermektedir. Netflix içeriklerinde izleyicilerin kendi ülkelerinin kültürüne ve anadiline uygun yapımların izleme tercihini ne yönde etkilediği araştırma içerisinde irdelenen konular arasında yer almaktadır. Söz konusu unsurların izleyicileri dijital platformlara yönlendirdiği ile ilgili soruya katılımcıların toplam \%53,5’i olumlu yanıt verirken \%33,24'ü olumsuz yanıt vermiştir. Kişilerin benimsemiş olduğu kültürel unsurların içeriklerde yer almasının önemli bir tercih sebebi olarak öne çıkması çalışmanın sonuçları arasında yer almaktadır. Dijital platform içerikleri ağıllıklı olarak küresel kültüre ilişkin unsurlar taşımaktadır.

Çalışmaya konu olan uluslararası dijital platform Netflix'in ABD merkezli olması ve alanda faaliyet gösteren benzer yapıların da ABD-Batı merkezli olması söz konusu içeriklerin yoğunlukla Batı kültürüne özgü unsurları taşımasına neden olmaktadır. Bu durum küreselleşmenin kültürel boyutunun özellikle Amerikan ve Batı kültürleri bağlamında kültürel bir homojenleşme süreci olarak betimlenmesiyle açıklanabilmektedir (Adıgüzel, 2011, s. 132). Katılımcılara Netflix’te yer alan içeriklerin başta Amerikan ve Batı kültürü olmak üzere farklı kültürel unsurları taşımasının tercihlerini hangi yönde etkilediğine dair yöneltilen soruya \%55,32 olumlu, \%30,38 ise olumsuz yanıt vermiştir. Bu noktada kararsız kalanların oranı dikkat çekmektedir. Katılımcıların \%12,20'si kararsız olduklarını belirtmişlerdir. Ancak rakamlar incelendiğinde farklı bir kültürel unsur taşıyan içeriğin izleme eğilimini çekici yönde etkilediği sonucuna varılabilmektedir.

Geleneksel televizyon yayını izleyicilerinin günümüzde en önemli sorunlarının başında reklam yayınları gelmektedir. Reklamsız izleme, dijital platformların abonelerine sunduğu en önemli seçeneklerden biri olma özelliğini taşımaktadır. Söz konusu özelliğin dijital platformlara yönelime ve bu platformlardaki izleme alıskanlığına olan etkisini belirlemek amacıyla katılımcılara yöneltilen soruya \%95,32 olumlu, \%2,06 olumsuz yanıt alınmıştır. Bulgular değerlendirildiğinde reklamsız izleme özelliğinin izleyici eğiliminde ve yöneliminde belirleyici unsur olduğu sonucuna varılmaktadır. İzleyici reklamsız izleme özelliğinin bulunduğu dijital platformlara yönelerek kullanımlar ve doyumlar yaklaşımında belirtildiği gibi aktif, etkiye direnen ve özgürce seçim yapabilen bir birey olarak öne çıkmaktadır (Erdoğan ve Alemdar, 1990, s. 109).

Geleneksel televizyon yayıncllı̆̆ ve Netflix içeriklerinin izleyiciler nezdindeki niteliğinin tespit edilmesi ve karşılaştırılması amacıyla katılımcılara yöneltilen sorulara verilen yanıtlar araştırma açısından önem taşımaktadır. Katılımcıların \%64,42'si Netflix’i katılımcı, yenilikçi ve çeşitli olarak nitelemiştir. Geleneksel televizyon yayıncılığının nitelendirilmesi istenen soruya ise katılımcıların \%77,39'u klasik ve eski moda yanıtını vermiştir. Araştırma bağlamındaki yanıtlar değerlendirildiğinde izleyicilerin dijital platformlara yöneliminde zevklerine hitap eden unsurları ön planda tuttukları sonucu elde edilebilmektedir.

Katılımcılara yöneltilen sorulara verilen yanıtlar çalışmanın geleneksel televizyon yayıncılı̆̆ı ve dijital platformların geleceğine ilişkin öngörülere ışık tutması açısından önem taşımaktadır. Televizyonda takip edilen bir dizi dijital platforma geçtiği takdirde söz konusu diziyi takip etmek için platforma üye olma durumuna yönelik soruya katılımcıların \%44,92'si olumsuz, \%31,42'si olumlu yanıt vermiştir. Katılımcıların \%22,07'sinin kararsız kalması ücretli üyelik durumunun izleyiciler nezdinde sorgulanmakta olduğu sonucuna varılmasına neden olmaktadır.

Dijital platformların yaygınlığının ve kullanılma düzeyinin artması sinema salonlarının geleceğine dair izleyicilerde ve yapımcılarda soru işaretleri oluşturmaktadır. Vizyonda olan bir sinema filminin aynı anda Netflix’te yayınlanması durumunda katılımcıların \%71,68'i “Netflix’ten izlerim”, \%12,20'si “Sinema salonunda izlerim", \%15,06’sı “Her ikisinde de izlerim" yanıtını vermiştir. "Netflix’ten izlerim” yanıt oranının kayda değer biçimde yüksek olması dijital platformların sinema salonlarına alternatif olması durumunun yakın gelecekte daha da artacağına işaret etmektedir. 
"Yaşadığınız yerde ikisinden birini seçmek zorunda kalsaydınız tercihinizi hangisinden yana kullanırdınız?" sorusuna katılımcıların \%82,59'u Netflix, \%15,58'i geleneksel televizyon yanıtını vermiştir. "Netflix'i yakın çevrenize tavsiye eder misiniz?" sorusuna ise katılımcıların \%92,46'sı “evet”, \%5,45’i "hayır” yanıtını vermiştir. Eğilimi ve tercihi ölçen bu sorulara verilen cevaplar değerlendirildiğinde izleyicilerin dijital platformlara yöneliminin yükselerek devam edeceği sonucu ortaya çıkmaktadır.

Dijital platformların yakın gelecekte ne şekilde konumlanacağına dair ön görülerde bulunulmasını sağlamak bu çalışmanın amaçları arasında yer almaktadır. Bu bağlamda "Televizyon yapımlarının yakın gelecekte yalnızca dijital platformlara taşınacağına inanıyorum.” ifadesine katılımcıların \%65,96'sı olumlu, \%20,51'i olumsuz yanıt vermiştir. Katılımcıların \%12,20'si kararsız kalırken \%13,50'si ise görüş belirtmemiştir. Cevap dağılımları incelendiğinde söz konusu ifadeye katılanların oranı yüksek olsa dahi kararsızların ve görüş belirtmeyenlerin oranı dikkat çekmektedir.

Dijital platformların içerik kalitesi ile çeşitliliği kullanıcıların izleme alışkanlıkları ve tercihleri konusunda belirleyici önem taşımaktadır. Reklamsız izleme deneyiminin sunduğu konfor alanı kullanıcı ve izleyici sadakatinin sürekliliğini sağlamaktadır. Kullanıcıların izleme deneyimi sırasında karşılaştıkları herhangi bir teknik sorunu hizmet sağlayıcıya eş zamanlı olarak rapor edebilmeleri (geri bildirim) ve içeriği takip etme açısından akıllı cihazlar arasında geçiş imkânına sahip olmaları önemli bir avantaj olarak öne çıkmaktadır. Netflix’teki herhangi bir içeriği evinde bulunan internet bağlantılı akıllı televizyonundan izlemeye başlayan kullanıcı, bir süre sonra evden çıktığında aynı içeriği izlemeye toplu taşıma aracında akıllı telefonundan devam edebilmektedir. Söz konusu durum dijital platform kullanıcılarının izleme alışkanlıklarının esnek koşullar çerçevesinde şekillendiğini ortaya koymaktadır.

Çalışmanın teorik temelini oluşturan kullanımlar ve doyumlar yaklaşımında aktif izleyiciyle ilgili iki sav bulunur. İlki izleyicinin seçme hakkı olduğu, ikincisi ise izleyicinin medya içeriğinden memnun olmadığı zaman elde-etme grupları vasıtasıyla medya kurumlarından talepte bulunma hakkıdır (Erdoğan ve Alemdar, 1990, s. 109).

Çalışmanın örneklemi olan Netflix başta olmak üzere dijital platformlar izleyiciye sunduklarıyla izleyicinin kullanımlar ve doyumlar çerçevesinde ihtiyaçlarını karşılamakta ve doyuma ulaşmalarını sağlamaktadır. Aynı zamanda dijital platformların çoklu ortamlarda izlenebilmeleri ve yeni medya üzerinden izleyici tartışmalarının ve yorumlarının yapıldığını göz önünde bulundurulduğunda Jenkins’in katılımcı kültür ve kollektif zekâ kavramları üzerinden araştırmanın bulgularını tartışmak faydalı olacaktır.

Kullanımlar ve doyumlar yaklaşımı çerçevesinde McQuail, Blumer ve Brown doyumları dörde ayırmıştır (Özmen, 2014, s.76):

1. Vakit geçirme: Günlük sorunlardan kaçma,

2. Kişisel ilişki: Arkadaşlık, toplumsal yarar,

3. Kişisel özdeşlik (kimlik): Toplumla ilgili olaylar hakkında bilgi alma, değerleri destekleme, gerçekleri arama.

4. Gözetme: Çevreyi bilip tanıma, olayla ve tüketim ürünleriyle ilgili bilgi edinme.

İzleyiciler medyadan bu ihtiyaçlarını karşılayarak doyuma ulaşırlar. İhtiyaçlarını karşılamak için medyayı kullanması izleyicinin "aktif izleyici” olarak konumlanmasını sağlamaktadır. 
Çalışmaya konu olan Netflix başta olmak üzere dijital platformlar izleyiciye çoklu dilde altyazı seçeneği, belli bir yayın akışına bağlı kalmadan istenilen saatte izleme yapabilme ve istenilen içerik türünü seçebilme özgürlüğü sunmaktadır ve bu yönüyle yaklaşımda dikkat çekilen seçim yapabilen aktif izleyicinin varlığını sürdürmesine hizmet etmektedir.

Fransız sosyolog Pierre Bourdieu'nün iletişim ve haberleşme teknolojileri ile medyayı "yeni kültür aracıları" olarak tasvir ettiği (Yılmaz ve Akyar, 2020, s. 7) göz önünde bulundurulduğunda dijital platformların da kültür ve bilgi taşıyıcısı olduğunu söylemek mümkün hale gelmektedir. Farklı bir kültüre dair içeriği izlemek söz konusu kültürden izleyicinin haberdar olması ve içerikte işleniş biçimine bağlı olarak zamanla çeşitli yönleriyle tanıması sonucunu doğurmaktadır. Çalışma kapsamında yapılan ankette yer alan "Netflix’te izlediğim içeriğin farklı bir kültürü (batı, Amerikan vb.) temsil etmesi benim için tercih sebebidir" ifadesine katılım düzeyine verilen cevaplar dijital platformların izleyiciye bu doyumu sağladığı yönündedir (\%17,40 kesinlikle katılıyorum, \%37,92 katılıyorum).

Dijital platformların içerik seçme özgürlüğü, zaman kısıtlamasından bağımsızlığı, çeşitli araçlarla (akıllı cihazlar, bilgisayar, tablet vb.) erişilebilme konforu yoluyla sağladığı doyumlar aktif izleyiciyi aynı zamanda kolektif zekânın da bir parçası haline getirmektedir. Ayrıca izleyicilerin dijital platformlardaki "beğendimbeğenmedim" butonları ile geri bildirimde bulunmaları interaktivite ve katılımcı kültürün kesişmesi anlamına gelmektedir. Aktif izleyici bu sayede "tercihe göre özelleştirilmiş interaktif bir medya" kullanıcısı olarak katılımcı kültür ve kolektif zekâ içindeki yerini almaktadır (Jenkins, 2006, s. 366).

Kitle iletişim araçlarının içeriği de kullanım ve doyuma ulaşma açısından önem taşımakta olduğundan İrfan Erdoğan içerik sınıflandırmasını şu şekilde yapmıştır (Özmen, 2014, s.76):

1. Gerçek-enformasyon veren içerik: Haber, belgesel sunuşlar ve yorumlar.

2. Gerçek-dokunaklı içerik: Bu içerik tipi tiyatro ya da oyun gibi estetik ve hayali değildir. Ancak gerçeğe dayanmasına rağmen bu içerik tipi çevreden uzaklaşma, kaçış ve hayali ilişkilere girmek için kullanılabilir. Canlı spor yayınlarını, konuşma programları ve reklamları örnek verilebilir.

3. Hayali-dokunaklı içerik: Roman, hikâye, filmler, televizyon oyunları örnek verilebilir. Bu tür içerik kişileri toplumsal ilişkilerde daha çok yalnızlığa götürür ve çoğunlukla sorunları çözme yerine sorunlardan kaçma olanağı verir.

Sınıflandırmadaki her üç içerik türü çalışmaya konu olan Netflix başta olmak üzere dijital platformlarda yer almaktadır. Çalışma kapsamında yapılan ankette katılımcılar en çok izledikleri ilk üç içeriğin dizi, Netflix orijinal içerikleri ve belgesel olduğunu belirtmişlerdir. Katılımcı kültürün aktif izleyicileri seçme özgürlüğüne sahip bir şekilde kendisine uygun olduğunu düşündüğü anlamlı içeriği tüketerek (Jenkins, 2006, s. 365) doyuma ulaşmaktadır.

Çalışma kapsamında yapılan ankete katılımcıların verdiği cevaplar dijital platformların izleme alışkanlıklarını bireysellik merkezli olarak şekillendirmekte olduğu yönündedir. Kişisel tercihlerin ön planda tutulması, platformun izlendiği cihaz türünün taşınabilirliği, reklamsız izleme deneyiminin, içerik seçimi özgürlügünün, platform algoritmasının kişinin sık izlediği içeriklere benzer tavsiyelerde bulunmasının ve içeriklerin detaylı kategorilere ayrılmasının tercih sebebi olarak belirtilmesi izleme deneyimindeki bireyselliği ve aktifliği çeşitli yönlerden vurgulamaktadır. İzleyicinin kullanımlar ve doyumlar yaklaşımında vurgusu yapılan "aktif" özelliğinin dijital platformlar yoluyla yeniden pekiştiği bu çalışmanın sonuçları arasında yer almaktadır.

İçerik seçimi özgürlüğü, farklı kültürel unsurları keşfetme isteğinin karşılanması, izleyiciye uygun tavsiye veren algoritma konforu, çoklu dilde altyazı-seslendirme seçeneği ve reklamsız izleme deneyimi gibi özellikler izleyicide yeni bir izleme deneyimi standardı oluşturmuştur. Çalışmanın bulguları genel olarak 
değerlendirildiğinde dijital platformların izleme alışkanlıklarını belirgin düzeyde etkilediği sonucu ortaya çıkmaktadır. Aktif izleyiciye yeni bir deneyim sunan dijital platformların bu gibi öne çıkan özellikleri nedeniyle yükselişinin devam edeceği ve izleyici eğiliminin platformlara yönelik artacağı da bu çalışmanın sonuçları arasında yer almaktadır.

\section{Kaynakça}

Adıgüzel, M. (2011). Ekonomik, kültürel ve politik küreselleşme ve sonuçları. Ankara: Nobel Yayınları.

Akkuş, T. (2019). Kan benim kanal benim. TRT Akademi Dergisi, 4(7), 179-183. Erişim adresi: https://dergipark.org.tr/tr/download/article-file/638800

Akyol, O. (2012). Developing television broadcasting technologies and interactive broadcasting practices. (Doktora Tezi). Erişim adresi: https://tez.yok.gov.tr/UlusalTezMerkezi/

Ateşalp, S.T. ve Başlar, G. (2020). İnternette dizi izleme pratiklerinin dönüşümü: Aşırı izleme (bingewatching) üzerine bir araştırma. Galatasaray Üniversitesi İletişim Dergisi, 32, 109-136. Erişim adresi: http://iletisimdergisi.gsu.edu.tr/en/download/article-file/1172185

Başer, E. ve Akıncı, S. (2020). Kullanıcı deneyimi ve kişiselleştirme bağlamında bir dijital platform incelemesi. Selçuk İletişim Dergisi, 13(2), 866-897. Erişim adresi: https://dergipark.org.tr/en/download/articlefile/1182103

Cereci, S. (2016) Televizyon sosyolojisi. Ankara: Phoenix Yayınevi.

Cevher, R. ve Ustakara, F. (2019). A research on social media usage within the context of uses and gratifications theory. Journal of Social, Humanities and Administrative Sciences, 5(19), 812-831. Erişim adresi: http://journalofsocial.com/DergiTamDetay.aspx?ID=166\&Detay=Ozet

Çil, S. (2015). Social sharing sites and democrazitation relation: Facebook example. (Yüksek Lisans tezi). Erişim adresi: https://tez.yok.gov.tr/UlusalTezMerkezi/

Dijk, J.V. (2016). A ̆ toplumu. İstanbul: Epsilon Yayınevi.

Erdoğan, İ. ve Alemdar, K. (1990). İletişim ve toplum: Kitle iletişim kuramları tutucu ve değişimci yaklaşımlar. Ankara: Bilgi Yayınevi.

Gürsakal, N. (2015) Betimsel istatistik. Bursa: Dora Yayıncılık.

İslamoğlu, A.H. ve Alnıaçı, Ü. (2016). Sosyal bilimlerde araştırma yöntemleri. İstanbul: Beta Yayınevi.

Jenkins, H. (2006). Convegence culture: Where old and new media collide. NewYork: NYU Press

Jenner, M. (2018). Netflix and the re-invention of television. UK, Cambridge: Anglia Ruskin University. 
Katmer, G. ve Sevindi, M.İ. (2020). Türkiye'de netflix'in serialler açısından genç geleneksel televizyon izleyici kullanım pratiklerine yansımaları. Medeniyet Sanat Dergisi, 6(1), 57-72. Erişim adresi: https://dergipark.org.tr/tr/pub/medeniyetsanat/issue/55869/760492

Mutlu, E. (2005). Kitle iletişim kuramları. Ankara: Ütopya Yayınevi.

Özçetin, B. (2018). Kitle iletişim kuramları: Kavramlar, okullar, modeller. İstanbul: İletişim Yayınları.

Özmen, S. (2014). Radyo ve televizyon okumaları. İstanbul: Derin Yayınları.

Özsoy, A. (2011). Televizyon ve izleyici: Türkiye'de dönüşen televizyon kültürü ve izleyici. Ankara: Ütopya Yayınevi.

Serim, Ö. (2007). Türk televizyon tarihi 1952-2006. İstanbul: Epsilon Yayıncılık.

Tanrı̈ver, H. (2011). Türkiye’de televizyon yayıncılı̆̆ı. İstanbul: İstanbul Ticaret Odası Yayınları.

Thompson, K.S. (1997). Sampling. NewYork: John Walley \& Sons Inc.

Timisi, N. (2003). Yeni iletişim teknolojileri ve demokrasi. Ankara: Dost Kitabevi.

Uluç, G. (2008). Küreselleşen medya: İktidar ve mücadele alanı. İstanbul: Kırmızı Yayınları.

Yaylagül, L. (2006). Kitle iletişim kuramları: Egemen ve eleştirel yaklaşımlar. Ankara: Dipnot Yayınları.

Yılmaz, B. ve Akyar, B.Y. (2020). Küreselleşme ve medya-ekonomi politiği bağlamında reklamveren unsurunun rolü: Türkiye'de yayınlanan reklamlarda kültürün aktarılması üzerine bir inceleme. IBAD Sosyal Bilimler Dergisi, 6, 1-19. Erişim adresi: https://bit.ly/2WcQpJU 


\section{Extended Abstract}

\section{Purpose}

Due to the prevalence of digital platforms today, the number of users of digital platforms is also increasing. Digital platform users have different viewing habits than the viewers of traditional television broadcasts. This situation makes it necessary to do research on the viewing habits of digital platform audiences. The purpose of this research is to determine the viewing habits of digital platform users. Within the scope of the study, answers to the following questions are sought:

- How do individuals' viewing habits affect their active audience position?

- Does the variety of tools (phones, tablets, portable computers, etc.) provided by the digital age have an impact on viewing habits?

- Are the content selection, content diversity and cultural elements in the productions effective on viewing habits?

In addition, questions that will enable to examine the permanence of today's audience preferences regarding the future of television broadcasting on digital platforms and to make predictions on the subject are also included in the study.

\section{Design and Methodology}

This study has been prepared as a research article. The aim of the study is to investigate the viewing habits of digital platform users through the Netflix example. CAWI was chosen as one of the data collection techniques in the study, which was carried out using the Purposive Sampling technique, and the data were obtained using a fully structured questionnaire. Participants were asked questions about the habits of watching Netflix digital platform content and their reasons for preference. Netflix common among international digital platforms is the main reason for choosing the sample to be the first platform operating in Turkey. The Uses and Gratifications Theory was used in the analysis of the data.

\section{Findings}

The findings of the study provided important inferences about the participant audience's watching habits and reasons for preference, the devices they use to access the content and the future of digital platforms. Findings indicate that digital platform watching habits are shaped within the frame of TV series and documentary productions. The computer comes first in accessing content on digital platforms. Besides, the main reasons for preference are the ability to access digital platforms from mobile devices, the quality of the productions, content diversity and freedom of content choice.

\section{Research Limitations}

Netflix users constitute the limitation of the research. Netflix is the first brand in the international digital platforms Turkey entered the market. Considering the high number of subscribers, the limitation of the research was determined in the context of Netflix users, resulting in more reliable results.

\section{Implications (Theoretical, Practical and Social)}

As a result of the study, determinations regarding the viewing habits of digital platform users and the reasons for their preference were reached. It has been determined that the variety of content, freedom of choice and the quality level of the productions directly affect the viewing habits of the users on digital platforms. It is 
among the results of this study that the "active" feature of the audience, emphasized in the uses and gratifications approach, is reinforced through digital platforms. In addition, it is among the results obtained in the study that the trend towards digital platforms will continue to increase in the near future.

One of the most striking elements in the viewing habits of digital platform users is the trend towards personalized features. For this reason, it will be beneficial for digital platform managers to give more importance to personalization in the services they will provide in the near future. The cultural elements carried by the productions are an important determinant in the habits of the audience. Digital platform companies should especially focus on cultural elements in the content they produce for country markets.

\section{Originality/Value}

In parallel with the trend worldwide there is increasing use in recent years in Turkey, despite the viewing habits of users digital platforms are very few studies on it. This study investigating the viewing habits of digital platform users fills an important gap.

Araştırmacı Katkısı: Ümit SARI (\%50), Halil TÜRKER (\%50). 